\title{
Learning Histology Through Game-Based Learning Supported by Mobile Technology
}

\author{
Enseñanza de la Histología a Través del Aprendizaje \\ Basado en Juegos Apoyado por Tecnología Móvil
}

Edgardo Rojas-Mancilla'; ${ }^{1}$ Daniel Conei ${ }^{2,3}$; Yanara A. Bernal ${ }^{1,4}$; Dan Astudillo ${ }^{5}$ \& Yuri Contreras ${ }^{1}$

ROJAS-MANCILLA, E.; CONEI, D.; BERNAL, Y. A.; ASTUDILLO, D. \& CONTRERAS, Y. Learning histology through gamebased learning supported by mobile technology. Int. J. Morphol., 37(3):903-907, 2019.

SUMMARY: Digital game-based learning and the testing effect have been shown to be effective in improving learning. The use of screens offers the opportunity to test innovative learning strategies in the classroom. Here, we report the impact of implementing a game and testing effect-based learning tool in a histology course. Seventy nine students participated in the study (mean age 19.5 years, $65 \%$ female). The students observed a slide-based class and then participated in a game, answering questions about key concepts, using their smartphones. Two surveys, asking about aspects related to perceptions/motivations and use of mobile technologies, were applied. The game allowed for immediate feedback, revealing student performance in every evaluated concept, and allowed teachers to give corrections after detecting conceptual mistakes. Students perceived the methodology as fun, interesting, interactive and attractive. Moreover, $96 \%$ of students participated and enjoyed the game and, among them, all agreed to use the methodology again. In parallel, about $87 \%$ of students use mobile technology to study and $97 \%$ to find academic information, frequently. The results indicate that the vast majority of students use mobile technology to study and positively perceive the game-based strategy. Strategies allowing fast feedback and dynamic relationships in the classroom could potentially improve significant learning on concept acquisition.

KEY WORDS: Game-based learning; Feedback; Undergraduate; Histology.

\section{INTRODUCTION}

Undergraduate students of today have unique skills in managing technological devices (Gambo et al., 2017). Various technologies have become important tools for learning support, including mobile technologies, such as smartphones and tablets. The use of digital games for formal learning purposes is growing among health educators and is also an area of research that has been gaining attention in the broader educational literature, with multiple studies exploring the value of digital games in developing cognitive abilities and functions (Morton et al., 2016). Much of this research has focused on whether games can be used by educators as effective learning tools, particularly in primary and secondary education and it has been increasingly tested in higher education environments (Hainey et al., 2016; Janssen et al., 2015). Mobile technologies have enabled learning to be more accessible, being widely used informally by undergraduate students (Burbules, 2012; Ciampa, 2014;
Dennen \& Hao, 2014; Janssen et al.) and proposed to be formally incorporated into curricula (Doyle et al., 2014).

Student learning and achievement could be improved through different learning techniques, and among them, testing effect has proven to be useful to improve learning, both in laboratory settings (Roediger \& Karpicke, 2006) and educational contexts (Dunlosky et al., 2013; Greving \& Richter, 2018). Testing effect is a technique that promotes retrieval practice, a strategy largely studied by psychologists and educators in different learning contexts for their strong impact on short-and long-term learning (Karpicke \& Blunt, 2011).

Smartphones allow to develop a wide range of applications and thus deliver content quickly, in a playful and dynamic manner (Callum et al., 2014). The use of digital

\footnotetext{
${ }^{1}$ Departamento de Ciencias Químicas y Biológicas, Universidad Bernardo O’Higgins, Santiago, Chile.

${ }^{2}$ Doctoral Program in Morphological Sciences, Faculty of Medicine, Universidad de La Frontera, Temuco, Chile.

${ }^{3}$ Department in Morphological Sciences, Faculty of Medicine and Science, Universidad San Sebastián, Puerto Montt, Chile

${ }^{4}$ Reproductive Health Research Institute (RHRI), Santiago, Chile.

${ }^{5}$ Universidad Iberoamericana de Ciencias y Tecnología, Santiago, Chile.
} 
games for teaching health topics is an important research niche today, given the potential they have for the development of spatial visualization skills, memory retention and to implement the testing effect, as demonstrated in several studies (Tsai \& Fan, 2013; Dunlosky et al.; Greving $\&$ Richter). Through the games, a number of competitive interactions are established by rules, with specific objectives that can be achieved by developing a skill. On this basis, the term game-based learning has been established, which is defined as the action of acquiring knowledge in scenarios with specific problems within a game (Wu et al., 2011).

To date, it has been demonstrated benefits of digital games in different health education themes, such as life support techniques, pediatrics and development of surgical skills, increasing mastery of content, motivations and positive attitudes (Pianfetti et al., 2001; Sward et al., 2008; Nguyen \& McDaniel, 2015). The field of morphological sciences is considered a complex matter for much of the students majoring in the area of health, given their diversity of subjects (anatomy, histology and embryology) and content base that are repeated during the plan studies (Anyanwu, 2014). Some experiences have shown that digital game can be a valuable tool to support the commitment of medical students with anatomy and histology content (Janssen et al.; Aktekin et al., 2018).

This article discloses the impact of the use of smartphones for a class of histology on perceptions and motivations of health sciences students, using a retrieval practice strategy, supported by the Kahoot! online application.

\section{MATERIAL AND METHOD}

The study included 4 courses and 82 undergraduate students from health sciences programs (mean age 19.5 years, $65 \%$ female). The game was applied after finishing the laboratory of histology, without obligation to participate. The teacher who applied the game was the same one who dictated the class and explained that the participation in the game was voluntary and without repercussions. Three students decided not to participate and were informed that they were free to leave the classroom. Inclusion criteria considered students from Kinesiology or Medical Technology, who attended the histology course. Only students that accepted to participate and signed the informed consent were included in the analysis.

Technology use survey. Students answered a survey that listed a series of electronic devices they use for academic purposes and how often they use every one, everyday. They were also asked about the frequency of use of their smartphone for academic and non-academic purposes from a list of academic and non-academic tasks.

Mobile-based game. A free application, Kahoot!, that allows to program questions in a format like trivia, was used to design 25 questions about basic concepts of the nervous system histology. At the end of the class, all students connected their smartphones to a webpage, introducing a code. Every student joined the virtual platform using their real names and then the game started. Randomly, 15 questions were shown and students had 20 seconds to answer. After every question, a ranking with scores obtained was shown and students were encouraged to compete for the first place. In the end, the percentage of mistakes for every question was shown, allowing the teacher to reinforce concepts that showed higher rates of mistakes.

Perception and motivations survey. Finally, an anonymous perception survey was applied to all groups, in order to determine how the student felt about the learning systems they used. The perception survey was conducted with a Likert scale consisting of 4 questions with 5 options, ranging from strongly disagree to strongly agree. The questions were explained and then students wrote short answers. The questions were:

1. What do you think about the use of trivia as a teaching strategy?

2. Would you like to use trivia again?

3. Was the trivia difficult to use?

4. This game, allowed you to better understand histology concepts?

Statistical analysis. The descriptive analysis was performed using frequency tables of categorical and dichotomous qualitative variables using absolute and relative frequencies. Quantitative variables were described by measures of central tendency (mean and median) and dispersion (standard deviation and interquartile range). Results were tabulated and analyzed using the software GraphPad Prism 6.0 (GraphPad Software, Inc., San Diego, CA, USA).

\section{RESULTS}

We found that $87 \%$ of students frequently use mobile technology to study and $97 \%$ of them to find academic information, most of them more than once a day (Table I).

The application of the game showed a positive attitude from students, among which $96 \%$ decided to 
Table I. Frequency of use of different technological devices, daily. Frequency of use per item, in percentage, is showed.

\begin{tabular}{lccccc}
\hline Device & $\begin{array}{c}\text { None } \\
\%(\mathrm{n})\end{array}$ & $\begin{array}{c}\text { Little } \\
\%(\mathrm{n})\end{array}$ & $\begin{array}{c}\text { Sometimes } \\
\%(\mathrm{n})\end{array}$ & $\begin{array}{c}\text { Frequently } \\
\%(\mathrm{n})\end{array}$ & $\begin{array}{c}\text { Almost always } \\
\%(\mathrm{n})\end{array}$ \\
\hline S martphone & $5.1(4)$ & $0.0(0)$ & $7.6(6)$ & $20.2(16)$ & $67.1(53)$ \\
Private notebook & $5.1(4)$ & $0.0(0)$ & $0.0(0)$ & $30.4(24)$ & $64.5(51)$ \\
University computer & $17.7(14)$ & $20.2(16)$ & $38.0(30)$ & $15.2(12)$ & $8.9(7)$ \\
\hline
\end{tabular}

participate in the activity. Furthermore, $87 \%$ consider the game easy to use, $92 \%$ assigned to it a value in learning and $100 \%$ would like to use the methodology in other classes (Table II). Finally, their subjective appreciations, obtained in the form of free comments, showed that students perceived the methodology as fun, interesting, interactive and attractive (Table III).

Table II. Perception of the methodology. Distribution of perception in items of usability, contribution to learning and if they would use it.

\begin{tabular}{lccc}
\hline & $\begin{array}{c}\text { Easy to use? } \\
\%(\mathrm{n}), \mathrm{n}=79\end{array}$ & $\begin{array}{c}\text { Useful to learn? } \\
\%(\mathrm{n}), \mathrm{n}=79\end{array}$ & $\begin{array}{c}\text { To use it again? } \\
\%(\mathrm{n}), \mathrm{n}=79\end{array}$ \\
\hline Yes & $87.3(69)$ & $92.4(73)$ & $100(79)$ \\
No & $12.7(10)$ & $7.6(6)$ & $0(0)$ \\
\hline
\end{tabular}

\section{DISCUSSION}

In this study, we report the impact of a methodology based on the testing effect and gaming, proving to be a good tool for quick feedback and as a motivating and challenging tool for students.

The relationship with the use of mobile technology to study and search for academic information, the results were the expected results, so that all students use a smartphone daily. On the positive attitude of the students to the use of Kahoot!, as its easy use and potential usefulness to learn, correlates with the perception of a fun, interesting, interactive and attractive methodology, being similar to what is shown in a study in which the undergraduate medical students had a positive attitude towards learning mobile (Pianfetti et al.). Testing effect could be useful when implemented appropriately, so, the factors affecting their implementation in the classroom should be considered (Nguyen \& McDaniel). For example, a question eliciting a low demand on retrieval effort to answer could not show the expected effect on learning (Greving \& Richter).

At the end of the game, the percentage of mistakes for every question was shown, allowing the teacher to reinforce concepts that showed higher rates of mistakes. Interestingly, most students reinforced some histological concepts, supporting the idea that the methodology improves the comprehension of technical concepts. Regarding aspects of the method, the best results were seen when 15 questions were applied in less than 10 minutes, demanding a total of 15 minutes, so it is compatible with various strategies to develop working memory and higher order skills (Agarwal et al., 2017). A previous study evaluated the value of digital games for teaching anatomy and histology, where through a digital platform and formed among participants sophomore studying medicine teams competed with each other. They conclude that digital

Table III. Perception of students. Selected comments, which represent the majority that are informative or detailed.

\begin{tabular}{cl}
\hline Student number & What do you think the use of trivia as a teaching strategy? \\
\hline 5 & It's entertaining, and it is not tedious as a class. \\
6 & Very creative and resourceful, sense of competition leads to increased motivation. \\
7 & An interactive and innovative way to integrate knowledge. \\
8 & A novel way that encourages student participation. \\
26 & Good to be lea rning concepts more entertainingly. \\
27 & Very good as it is competitive side and we learn at the same time. \\
30 & I found an educational and entertaining way to learn concepts and remember. \\
33 & Very good, because here it is checked what was studied in class. \\
39 & Fun, a good way to learn and remember past stuff. \\
40 & Fine, entertaining, it gives the opportunity to learn. \\
51 & Very successful, great idea to capture learning in a didactic way. \\
72 & It was good to learn, but the time to answer is too short. \\
\hline
\end{tabular}


platforms are an important alternative tool for exploring their strengths and weaknesses in knowledge, in addition to motivate them to study (Jassen et al.). Thus, the use of cell phones does not come to change any learning environment, rather it comes to offer an additional resource to support teaching and learning.

The use of smartphones for learning has been shown to modify the learning environment to turn any situation into an innovative and collaborative environment (Gambo et al.), which was observed during application in our students. Franco (2008) reports that there are plenty of students who use the applications of smartphones to carry out their tasks in work or study, through the internet, so it is a familiar tool for students, being a very easy run, where $100 \%$ of the participants said it was easy to use.

A relevant issue to consider is that most of the teachers have some resistance to the use of technology in the classroom (Balash et al., 2011). This is based on two aspects, namely how difficult it can be for educators to learn the use of a new technology, as well as develop the ability to integrate it into teaching (Gambo et al.; Kebritchi, 2010). If not supported and accepted by educators, it will be difficult to integrate knowledge through this pathway (Venkatesh et al., 2003). So, validating and spreading applications that reduce barriers to use by teachers, could favor the incorporation of mobile technologies in learning processes in the classroom. Finally, it is relevant to consider that Kahoot! has been presented as a model to show the potential of digital technologies on motivation in a classroom. Other digital games, platforms and resources have proven to be as useful, dynamic and user friendly as Kahoot!, named Socrative, Quizizz, code.org, cerebriti, KnowRe, Cristic, among others (Aktekin et al.).

Another aspect to consider is the terminology used in these fields, which is considered by students as difficult to retain. This challenge could be addressed applying testing effect through tools like Kahoot! (Aktekin et al.; Greving \& Richter).

Our challenge is that, in higher education, the use of technology for learning is in the process of adaptation, understanding and analysis (Ciampa; Dennen \& Hao). Burbules defines "ubiquitous learning" as one who does "make the learning experience more distributed in time and space". Despite this, there are few studies about the use of digital games for teaching morphology in health sciences. Furthermore, increasing online resources are offering anatomical and histological information in visual digital formats, offering interactive tools susceptible to be used in mobile devices.

\section{CONCLUSION}

In conclusion, students positively perceive the strategy and it offers a fast feedback tool, to reinforce key concepts in the classroom. Strategies allowing dynamic relationships in the classroom plus motivating interventions will allow improving significant learning on concepts acquisition through morphological disciplines in undergraduate students.

\section{ACKNOWLEDGEMENTS}

This study was supported by Dirección de Docencia, Universidad Bernardo O'Higgins.

ROJAS-MANCILLA, E.; CONEI, D.; BERNAL, Y. A.; ASTUDILlO, D. \& CONTRERAS, Y. Enseñanza de la histología a través del aprendizaje basado en juegos apoyado por tecnología móvil. Int. J. Morphol., 37(3):903-907, 2019.

RESUMEN: El aprendizaje basado en juegos digitales y pruebas han demostrado ser efectivos en el mejoramiento del aprendizaje. El uso de pantallas ofrece la oportunidad de probar estrategias de aprendizaje innovadoras en el aula. En este estudio se presenta el impacto de la implementación de una herramienta de aprendizaje basada en juegos y pruebas aplicadas en un curso de histología. Setenta y nueve estudiantes participaron en el estudio (edad promedio 19,5 años, $65 \%$ mujeres). Los estudiantes observaron una clase basada en diapositivas y luego participaron en un juego, respondiendo preguntas sobre conceptos clave, utilizando sus teléfonos inteligentes. Se aplicaron dos encuestas, preguntando sobre aspectos relacionados con las percepciones/motivaciones y el uso de tecnologías móviles. El juego permitió una retroalimentación inmediata, revelando el desempeño de los estudiantes en cada concepto evaluado, y permitió a los profesores dar correcciones cuando se detectaron errores conceptuales. Los estudiantes percibieron la metodología como divertida, interesante, interactiva y atractiva. Además, el $96 \%$ de los estudiantes participaron y disfrutaron del juego y, de ellos, todos relataron la intención de utilizar la metodología nuevamente. En paralelo, $87 \%$ de los estudiantes utilizan la tecnología móvil para estudiar y el $97 \%$ para encontrar información académica, frecuentemente. Los resultados indican que la gran mayoría de los estudiantes usa tecnología móvil para estudiar y perciben positivamente la estrategia basada en juego. Las estrategias que permiten retroalimentación rápida y relaciones dinámicas en el aula podrían potencialmente mejorar el aprendizaje significativo en la adquisición de conceptos.

PALABRAS CLAVE: Aprendizaje basado en juegos; Retroalimentación; Pregrado, histología. 


\section{REFERENCES}

Agarwal, P. K.; Finley, J. R.; Rose, N. S. \& Roediger, H. L. 3rd. Benefits from retrieval practice are greater for students with lower working memory capacity. Memory, 25(6):764-71, 2017.

Aktekin, N. C.; Çelebi, H. \& Aktekin, M. Let's Kahoot! Anatomy. Int. J. Morphol., 36(2):716-21, 2018.

Anyanwu, E. G. Anatomy adventure: a board game for enhancing understanding of anatomy. Anat. Sci. Educ., 7(2):153-60, 2014.

Balash, F.; Yong, Z. \& Bin Abu, B. Lecturers and Educational Technology: Factors Affecting Educational Technology Adoption in Teaching. Proceedings of the 2nd International Conference on Education and Management Technology. IPEDR, 13. Jurong West, IACSIT Press, 2011.

Burbules, N. C. Ubiquitous learning and the future of teaching. Encount. Educ., 13:3-14, 2012.

Callum, K. M.; Jeffrey, J. \& Kinshuk. Factors impacting teachers' adoption of mobile learning. J. Inf. Technol. Educ. Res., 13(1):141-62, 2014.

Ciampa, K. Learning in a mobile age: an investigation of student motivation. J. Comput. Assist. Learn., 30(1):82-96, 2014.

Dennen, V. P. \& Hao, S. Intentionally mobile pedagogy: the M-COPE framework for mobile learning in higher education. Technol. Pedag. Educ., 23(3):397-419, 2014.

Doyle, G. J.; Garrett, B. \& Currie, L. M. Integrating mobile devices into nursing curricula: opportunities for implementation using Rogers' Diffusion of Innovation model. Nurse Educ. Today, 34(5):775-82, 2014.

Dunlosky, J.; Rawson, K. A.; Marsh, E. J.; Nathan, M. J. \& Willingham, D. T. Improving students' learning with effective learning techniques: promising directions from cognitive and educational psychology. Psychol. Sci. Public Interest, 14(1):4-58, 2013.

Franco, C. de P. Using wiki-based peer-correction to develop writing skills of Brazilian EFL learners. Novitas-ROYAL, 2(1):49-59, 2008.

Gambo, J. M.; Bahreman, N. T.; Watties-Daniels, D.; Neal, M. \& Swoboda, S. M. Can mobile technology enhance learning and change educational practice? Comput. Inform. Nurs., 35(8):375-80, 2017.

Greving, S. \& Richter, T. Examining the testing effect in university teaching: retrievability and question format matter. Front. Psychol., 9:2412, 2018.

Hainey, T.; Connolly, T. M.; Boyle, E. A.; Wilson, A. \& Razak, A. A systematic literature review of games-based learning empirical evidence in primary education. Comput. Educ., 102(C):202-23, 2016.

Janssen, A.; Shaw, T.; Goodyear, P.; Kerfoot, B. P. \& Bryce, D. A little healthy competition: using mixed methods to pilot a team-based digital game for boosting medical student engagement with anatomy and histology content. B. M. C. Med. Educ., 15:173, 2015.

Karpicke, J. D. \& Blunt, J. R. Retrieval practice produces more learning than elaborative studying with concept mapping. Science, 331(6018):772-5, 2011.

Kebritchi, M. Factors affecting teachers' adoption of educational computer games: A case study. Br. J. Educ. Technol., 41(2):256-70, 2010.

Morton, C. E.; Saleh, S. N.; Smith, S. F.; Hemani, A.; Ameen, A.; Bennie, T. D. \& Toro-Troconis, M. Blended learning: how can we optimise undergraduate student engagement? B. M. C. Med. Educ., 16:195, 2016.

Nguyen, K. \& McDaniel, M. A. Using quizzing to assist student learning in the classroom: the good, the bad, and the ugly. Teach. Psychol., 42(1):87-92, 2015.

Pianfetti, E. S. Focus on research: teachers and technology: digital literacy through professional development. Lang. Arts, 78(3):255-62, 2001.

Roediger, H. L. 3rd \& Karpicke, J. D. The power of testing memory: basic research and implications for educational practice. Perspect. Psychol. Sci., 1(3):181-210, 2006.

Sward, K. A.; Richardson, S.; Kendrick, J. \& Maloney, C. Use of a Webbased game to teach pediatric content to medical students. Ambul. Pediatr., 8(6):354-9, 2008.
Tsai, C. W. \& Fan, Y. T. Research trends in game-based learning research in online learning environments: A review of studies published in SSCIindexed journals from 2003 to 2012. Br. J. Educ. Technol., 44(5):E1159, 2013.

Venkatesh, V.; Morris, M. G.; Davis, G. B. \& Davis, F. D. User acceptance of information technology: toward a unified view. MIS Q., 27(3):42578, 2003.

Wu, W. H.; Hsiao, H. C.; Wu, P. L.; Lin, C. H. \& Huang, S. H. Investigating the learning-theory foundations of game-based learning: a metaanalysis. J. Comput. Assist. Learn., 28(3):265-79, 2011.

Corresponding author:

Dr. Edgardo Rojas-Mancilla

Departamento de Ciencias Químicas y Biológicas

Universidad Bernardo O'Higgins

General Gana 1780

8370854, Santiago

CHILE

Email:edgardo.rojas@ubo.cl

Received: 28-02-2019

Accepted: 30-04-2019 